\title{
Criminal law policy on environmental crimes in context of sustainable development in Vietnam
}

\author{
Thi Mai Dinh ${ }^{1, *}$, and Dinh Luan Nguyen ${ }^{2}$ \\ ${ }^{1}$ Graduate Academy of Social Sciences, Nguyen Trai Street, No. 477, Thanh Xuan District, Ha Noi, \\ 10000, Vietnam \\ ${ }^{2}$ Economic Security Department, Ha Tinh Police Department, Ha Tinh province, 45000, Vietnam
}

\begin{abstract}
Balancing between economic growth and environmental protection is the core of sustainable development. However, both developed and developing countries are facing many difficulties in dealing with global challenges such as climate change, pollution and resource shortage. In an effort to promote environmental protection and legislate punishment, environmental crimes have been included in criminal law. In order to increase its effectiveness, criminal law on environmental crimes need to be further specified, such as identification of environmental offences, inclusion of new offences, expansion of scope of application, increase on fine, and supplement existing sanctions for environmental offences. These changes can bring tremendous impacts on Vietnam's sustainable development in the near future.
\end{abstract}

\section{Introduction}

In recent years, the application of criminal law in the field of environmental protection has achieved positive results, but has revealed many difficulties and obstacles. Acts of violating environmental laws, especially those with signs of criminal offences, have increased in quantity and complexity. Environmental crimes in Vietnam are most common in the following areas:

- In industrial production. Vietnam's open door policy and investment attraction incentive policies have attracted local and foreign investors. However, many of industrial projects in Vietnam have taken advantages of gaps in existing environmental regulations to neglect waste management. This situation is particularly common in industrial parks under facility improvement or in areas near rivers, such as industrial parks in Dong Nai province near Dong Nai river, parks in the Mekong Delta near Mekong river, and parks in Hong River Delta near Hong river. It is more alarming when there have been cases of enterprises with a complete waste treatment system yet continue to deliberately discharge untreated waste into the environment.

- In waste trading. Illegal waste import into Vietnam in the form of raw materials and used technology, with the promise of temporary import for re-export, poses the risk of

*Corresponding author: dinhthimai@gmail.com 
turning Vietnam into an "industrial dump". Some waste import companies take advantage of chance inspection or bribe inspectors so that their imported goods can pass environmental standards required for customs clearance.

- In the exploitation of natural resources and minerals. Deforestation in Vietnam has always been an urgent issue. Policies such as forest conversion construction, hydropower construction and border clearance have unfortunately provided chances for the destruction of virgin forests, protection forests and natural reserves. When violation cases are intervened by responsible government personnel, resistance occurs, creating social disruption in many provinces.

- In wildlife hunting and trade. Illegal wildlife trade still occurs publicly in Vietnam. The high economic benefits brought by trading of endangered species such as tiger and pangolin makes illegal wildlife trading an issue difficult to terminate.

- In craft production at craft villages. Due to small-scale household production, manual and low-tech production, traditional craft production fails to consider waste treatment, leading to alarming pollution in craft villages.

\section{Data and Research Methods}

Until now there has not been any formal evaluation of damages caused by environmental crimes in Vietnam. Researchers also find it difficult to estimate the number or scale of impacts and damages. This article discussed criminal law on environmental crimes, thus we used official data collected by law enforcement agencies in Vietnam. Selected data included: (i) Statistics of prosecution and trials of environmental crimes at the Supreme People's Court from 2008 to 2018, and (ii) statistics of environmental administrative violations (without criminal prosecution) at the Environmental Police Department, Ha Tinh Province Police Department, from 2010 to 2019. Only data on dismissed cases were included. All data were drawn from reports, not raw data. This article also used data published in a doctoral thesis on environmental crime in Vietnam by Nguyen Huu Hoa (2019) [4].

The new Vietnam's Criminal Code was issued in 2015, amended in 2017 and come into force as of January 1, 2018. Cases occurring before 2018 are under the regulation of the 1995 Criminal Code. As such, to analyze the effect of the 1995 Criminal Code on handling environmental offences, we included data of cases occurred before 2018. In other words, while criminal policy on environmental crimes were analyzed in two periods (1985-2014 and 2015-present), the situation of environmental crimes in Ha Tinh province was analyzed in one period (2010-2019).

\section{Results}

\subsection{Vietnam's criminal law policy on environmental crimes in the 1985-2014 period}

After more than 30 years of renovation, Vietnamese people have experienced better material and mental life thanks to remarkable socio-economic development. Foreign investment attraction incentive policy has made Vietnam a good place for investment from Japan, Korea, Taiwan, etc. Newly built industrial parks across the country, fast-paced urbanization and strong increase in import-export activities have boosted economic growth and brought a new face to Vietnam's infrastructure. However, the cost of industrialization and urbanization is serious pollution. Environmental crimes happen more frequently in an increasingly complex and organized manner, leading to severe consequences. The high cost 
of tradeoff for socio-economic development has raised the need for sustainable development.

Environmental crime first appeared in Vietnam's 1985 Criminal Code (right before the renovation period), although the perception of environmental crime remains primitive at the time. Besides Article 195 on "Breaching environmental regulations causing serious consequences", there are 4 articles in the 1985 Criminal Code related to environmental protection yet classified under economic offences and offences against administrative management order. This implies that while Vietnamese lawmakers had been aware of ensuring environment protection through criminal law, early regulations of environmental offences were ambiguous, while contemporary regulations of public environment and disease prevention were too general to define serious consequence.

Criminal sanctions on environment are improved in the 1999 Criminal Code, which was later amended in 2009. Better perception of environmental crimes allowed lawmakers to devote a chapter with 11 articles (from Article 182 to Article 191a) on environmental offences, including the following acts: (i) causing air pollution, (ii) causing water source pollution, (iii) causing land pollution, (iv) import of technologies, machinery, equipment, discarded materials or materials which fail to satisfy environmental protection criteria, (v) spreading dangerous epidemics to human beings, (vi) deliberately spreading dangerous epidemics to animals and/or plants, (vii) destroying aquatic resources, (viii) destroying forest, (ix) breaching regulations on the protection of precious and rare wild animals, and (x) breaching the special-protection regime for nature preservation areas. Other environment-related offences in the 1999 Criminal Code are: Article 172 on "Breaching regulations on natural resource surveys, exploration and/or exploitation", and Article 175 on "Breaching regulations on forest exploitation and protection". However, these two articles were classified under crimes of infringing upon the economic management order.

Compared to the 1985 Criminal Code, regulations on environmental offences in the 1999 Criminal Code are more specific, reflecting higher legislative techniques. Pollution was specified as water source pollution, air pollution, land pollution, technological pollution, destruction of nature conservation, etc., The lawmakers had drawn a fairly comprehensive picture of environmental crimes in Vietnam. However, the 1999 Criminal Code failed to meet the requirements of actual practice in fighting and preventing environmental crimes. It did not provide legal grounds to handle criminal acts of environmental offences; the distinction between criminal enforcement and administrative enforcement for environmental legislation was unclear and hard to apply, leading to omissions of criminal offence or criminalization of administrative violations. Regulations on environmental crimes in the 1999 Criminal Code also felt short to international cooperation requirements when Vietnam signed international treaties in environment protection.

Statistics of the Supreme People's Court of Vietnam show that, despite the increase in air and water pollution, deforestation and illegal wildlife trading, environmental crimes from 2008 to 2018 accounted for only $0.34 \%$ of the total number of criminal cases nationwide and $0.35 \%$ of the total number of defendants committing crimes.

Table 1. National statistics on environmental crimes and defendants in the 2008-2018 period (Source: Reports of the Supreme People's Court on first instance trials).

\begin{tabular}{|c|c|c|}
\hline Year & $\begin{array}{c}\text { Number of environmental offences } \\
\text { over total number of offences }(\%)\end{array}$ & $\begin{array}{c}\text { Number of defendants in environmental } \\
\text { cases over total number of defendants }(\%)\end{array}$ \\
\hline 2008 & $131 / 58,174=0.22$ & $215 / 98,314=0.21$ \\
\hline 2009 & $125 / 60,433=0.20$ & $285 / 102,577=0.27$ \\
\hline 2010 & $123 / 51,864=0.23$ & $208 / 86,883=0.23$ \\
\hline 2011 & $251 / 57,165=0.43$ & $424 / 97,678=0.43$ \\
\hline 2012 & $272 / 65,740=0.41$ & $495 / 117,409=0.42$ \\
\hline
\end{tabular}




\begin{tabular}{|c|c|c|}
\hline 2013 & $294 / 66,976=0.43$ & $582 / 117,979=0.49$ \\
\hline 2014 & $198 / 66,511=0.29$ & $308 / 118,933=0.25$ \\
\hline 2015 & $174 / 59,755=0.29$ & $250 / 106,162=0.23$ \\
\hline 2016 & $221 / 61,776=0.35$ & $336 / 103,903=0.32$ \\
\hline 2017 & $268 / 57,746=0.46$ & $423 / 94,453=0.44$ \\
\hline 2018 & $263 / 58,570=0.45$ & $435 / 98,463=0.44$ \\
\hline Total & $2,320 / 664,710$ & $3,961 / 1,142,754$ \\
\hline Average & 0.34 & 0.35 \\
\hline
\end{tabular}

\subsection{Administrative and criminal enforcement of environmental policy: case study of Ha Tinh province in the $2010-2019$ period}

Making a comparision between administrative penalties for violation of environmental legislation and environmental crimes in Ha Tinh province from 2010 to 2019 shows that:

Fact 1: The administrative penalties for environmental violation in Ha Tinh Province increased steadily and reached $200 \%$ in the period 2010 to 2019 .

Table 2. Statistics of violation of environmental legislation in Ha Tinh province from 2010 to 2019

(Source: Annual reports of Environmental Police Department, Ha Tinh Provincial Police Department).

\begin{tabular}{|l|c|l|c|c|c|l|}
\hline Year & \multicolumn{2}{|c|}{ Total number of cases } & \multicolumn{2}{c|}{$\begin{array}{c}\text { Number of cases with } \\
\text { administrative penalties }\end{array}$} & \multicolumn{2}{|c|}{$\begin{array}{c}\text { Number of criminal } \\
\text { cases }\end{array}$} \\
\hline 2010 & 786 & $100 \%$ & 786 & $100 \%$ & 0 & $100 \%$ \\
\hline 2011 & 788 & $100.2 \%(+0.2 \%)$ & 788 & $100.2 \%(+0.2 \%)$ & 0 & $100 \%(=0 \%)$ \\
\hline 2012 & 912 & $116 \%(+16 \%)$ & 910 & $115.7 \%(+15.7 \%)$ & 02 & $200 \%(+200 \%)$ \\
\hline 2013 & 1,534 & $195.1 \%(+95.1 \%)$ & 1,528 & $194.4 \%(+94.4 \%)$ & 06 & $600 \%(+600 \%)$ \\
\hline 2014 & 1,668 & $\begin{array}{l}212.2 \%(+ \\
112.2 \%)\end{array}$ & 1,662 & $211.4 \%(+111.4 \%)$ & 06 & $600 \%(+600 \%)$ \\
\hline 2015 & 1,777 & $226 \%(+126 \%)$ & 1,770 & $225.1 \%(+125.1 \%)$ & 07 & $700 \%(+700 \%)$ \\
\hline 2016 & 1.843 & $\begin{array}{l}234.4 \% \\
(+134.4 \%)\end{array}$ & 1.835 & $233.4 \%(+133.4 \%)$ & 08 & $800 \%(+800 \%)$ \\
\hline 2017 & 1.863 & $237 \%(+137 \%)$ & 1,848 & $235.1 \%(+135.1 \%)$ & 15 & $1500 \%(+1500 \%)$ \\
\hline 2018 & 2,033 & $\begin{array}{l}258.6 \% \\
(+158.6 \%)\end{array}$ & 2.016 & $256.4 \%(+156.4 \%)$ & 17 & $1700 \%(+1700 \%)$ \\
\hline 2019 & 2,398 & $305 \%(+205 \%)$ & 2,381 & $302.9 \%(+202.9 \%)$ & 17 & $1700 \%(+1700 \%)$ \\
\hline
\end{tabular}

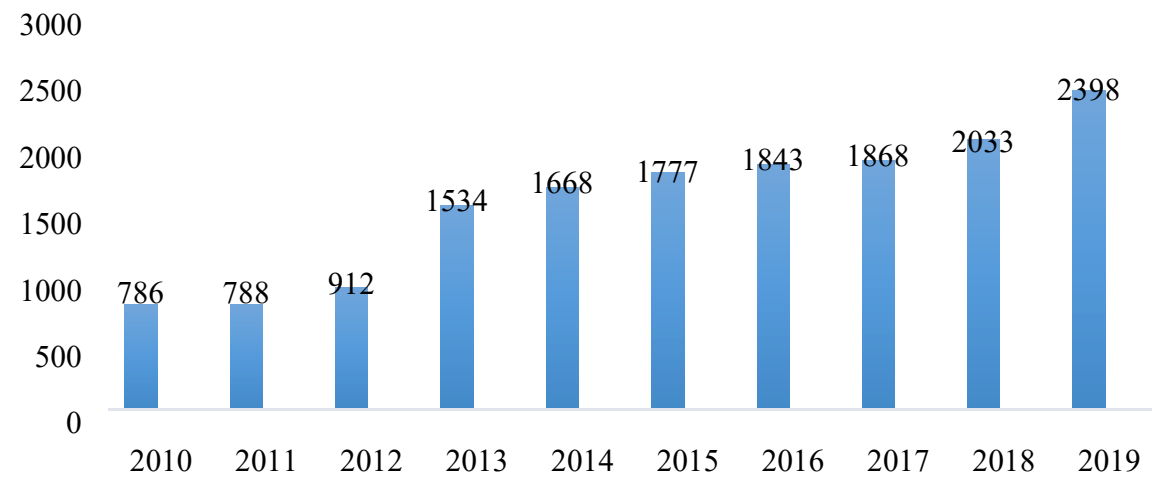

Fig. 1. Number of cases of violations of environmental laws in Ha Tinh province from 2010 to 2019 (Source: Annual reports of Environmental Police Department, Ha Tinh Provincial Police Department). 


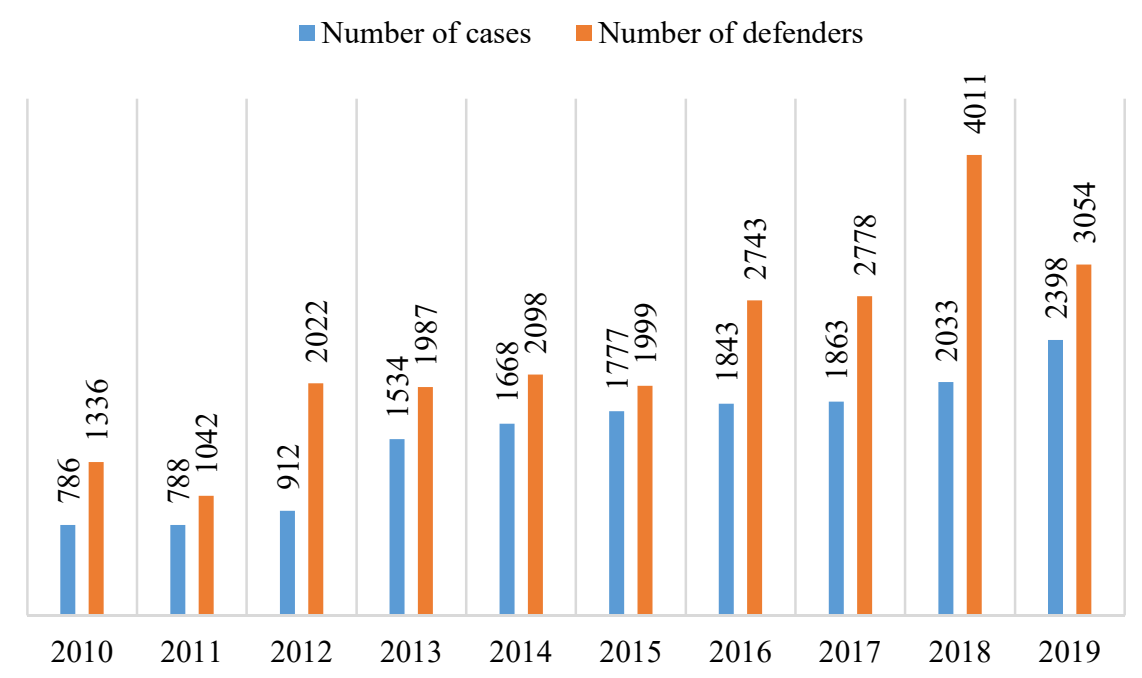

Fig. 2. Number of cases with administrative penalties and number of defenders in cases with administrative penalties in Ha Tinh province from 2010 to 2019 (Source: Annual reports of Environmental Police Department, Ha Tinh Provincial Police Department).

Fact 2: The criminal handling rate for environmental law violations in Ha Tinh is extremely low. Among 15,607 serious violations of environmental administrative cases in Hatinh Provice (from 2010-2019), there were only 78 criminal cases (accounting for only $1 \%)$.

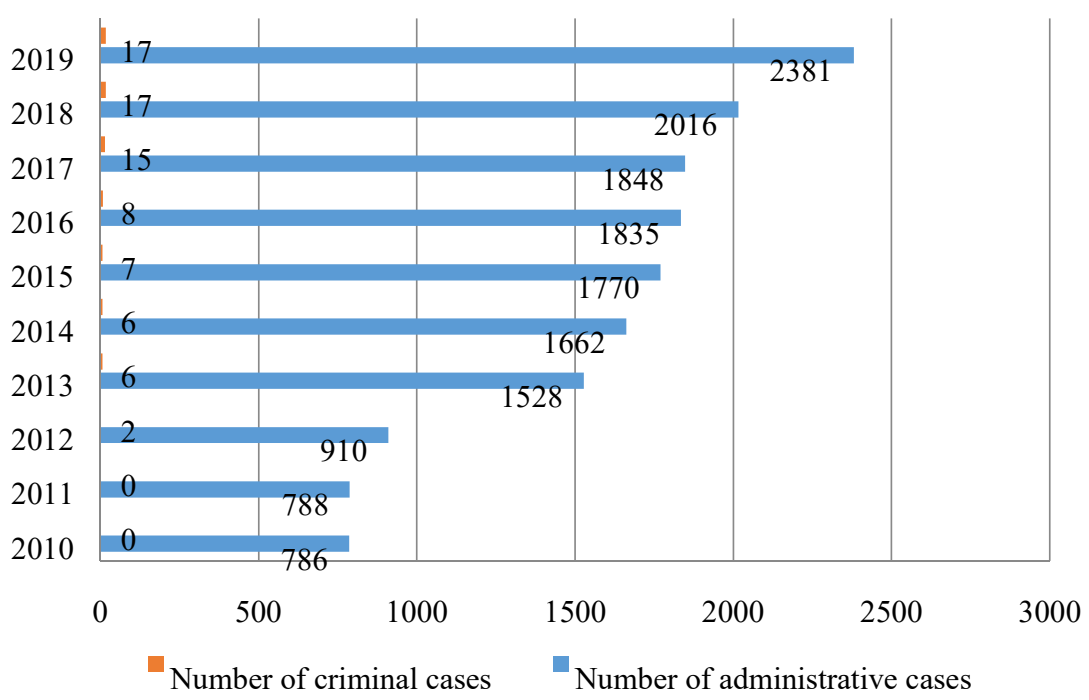

Fig. 3. Comparison between administrative and criminal enforcement of environmental policy in $\mathrm{Ha}$ Tinh province from 2010 to 2019 (Source: Annual reports of Environmental Police Department, Ha Tinh Provincial Police Department). 


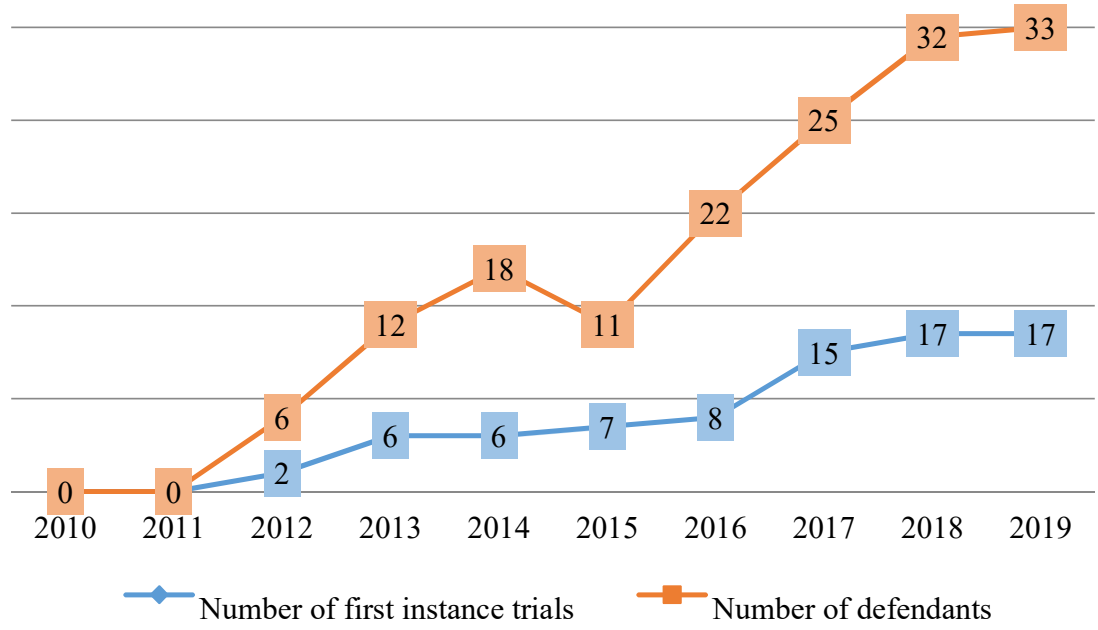

Fig. 4. Number of prosecution cases and defendants committing environmental crimes in Ha Tinh province from 2010 to 2019 (Source: Annual reports of Environmental Police Department, Ha Tinh Provincial Police Department).

\subsection{New changes in the Criminal Code on environmental crimes in 2018: amendments to meet the requirements of sustainable development in Vietnam}

To meet new requirements on environmental protection and sustainable development in Vietnam, the new 2015 Criminal Code, amended in 2017 and come into force from $1^{\text {st }}$ January 2018 has included legislation on environmental crimes. In this part we discussed the characteristics of these changes.

The 2015 Criminal Code with amendments in 2017 consists of 12 articles on environmental crime (Article 235 to Article 246). The structure of the articles was completely revised in comparison to the 1999 Criminal Code, with one additional article: Article 238 on Offences against regulations on protection of irrigation works, embankments, and disaster protection works; offences against regulations on protection of river banks. Compared to the previous Criminal Code, legislation on environmental offences in the new Code were better quantified in term of weight, volume and composition of discharged waste, affected area, etc. For example, types of hazardous wastes or persistent organic pollutants were specified by a reference to Appendix A of Stockholm Convention on persistent organic pollutants against the law; the amount of discharged waste were quantified, such as weight $(\mathrm{kg})$ of solid wastes or volume $\left(\mathrm{m}^{3}\right)$ of wastewater and dust/exhaust gas. These quantitative measures provide a firm ground to distinguish between criminal acts and administrative offence in environment protection.

The difference between the two Criminal Codes are evident when specific articles are compared.

Article 182 in the 1999 Criminal Code on causing air pollution stipulated that:

"1. Those who discharge into the air different kinds of smoke, dust, toxic matters or other harmful elements; emit radiation and/or radioactive elements in excess of the permitted criteria, have already been administratively sanctioned but still deliberately refuse to apply remedial measures under the decisions of the competent agencies, thus 
causing serious consequences, shall be subject to a fine of between ten million dong and one hundred million dong, non-custodial reform for up to three years or a prison term of between six months and three years.

2. Committing the crime and causing very serious consequences, the offenders shall be sentenced to between two years and seven years of imprisonment.

3. Committing the crime and causing particularly serious consequences, the offenders shall be sentenced to between five and ten years of imprisonment.

4. The offenders may also be subject to a fine of between five million dong and fifty million dong, a ban from holding certain posts, practicing certain occupations or doing certain jobs for one to five years."

The above regulations are qualitative, making them difficult to apply in practice. The Code failed to specify types of smoke, dust, toxic matters against the law or the allowed level of radiation. There was no clear indication of serious and very serious consequences. The vague regulation led to spontaneous implementation: case perception was greatly influenced by the subjective will of law enforcers, leading to omission or injustice.

Meanwhile, Article 235 of the 2015 Criminal Code specified the amount of solid, liquid and gaseous wastes against the law, the list of wastes according to international standards, and the volume of waste discharged into the environment to qualify for serious and very serious consequences. Crime consequences were measured in kilograms and cubic meters, such as prescribed in Point a, Clause 1, Article 235: Illegally burying, dumping, discharging into the environment from $1,000 \mathrm{~kg}$ to under $3,000 \mathrm{~kg}$ of hazardous wastes that contain extremely hazardous constituents beyond the limits prescribed by law or hazardous wastes in Appendix A of Stockholm Convention on persistent organic pollutants or from $3,000 \mathrm{~kg}$ to under $10,000 \mathrm{~kg}$ of other hazardous wastes.

All 12 articles demonstrated the specification of criminal acts in environment protection, thus ensuring legal feasibility and a clear distinction between environmental offences and other criminal offences.

The specification of qualitative and quantitative requirements of environmental crimes has both educational and deterrence effects. Perception of criminal cases no longer depends on subjective will of the law enforcers but is based on evidence. This change has met the requirement of environmental crime prevention and sustainable development in Vietnam.

Table 3. National statistics on the first instance trials and defendants in environmental crimes in the 2008-2018 (Source: Reports of the Supreme People's Court on first instance trials).

\begin{tabular}{|c|c|c|}
\hline Year & $\begin{array}{c}\text { Environmental } \\
\text { Crimes Cases }\end{array}$ & $\begin{array}{c}\text { Environmental } \\
\text { defendants }\end{array}$ \\
\hline 2008 & 131 & 215 \\
\hline 2009 & 125 & 285 \\
\hline 2010 & 123 & 208 \\
\hline 2011 & 251 & 424 \\
\hline 2012 & 272 & 495 \\
\hline 2013 & 294 & 582 \\
\hline 2014 & 198 & 308 \\
\hline 2015 & 174 & 250 \\
\hline 2016 & 221 & 336 \\
\hline 2017 & 268 & 423 \\
\hline 2018 & 263 & 435 \\
\hline Total & $\mathbf{2 . 3 2 0}$ & $\mathbf{3 . 9 6 1}$ \\
\hline
\end{tabular}

If 2008 data are used as the reference point (100\%), the number of first instance trials of environmental crimes in 2009 reduced $4.6 \%$ but the number of defendants increased $32.5 \%$. The number of first instance trials in 2010 decreased $6.1 \%$ and the number of defendants also decreased $3.3 \%$ in comparison to 2008 . The number of trials in 2011 increased $91.6 \%$ 
and the number of defendants increased $97.2 \%$ compared to 2008 . The number of trials in 2012 increased $107.6 \%$ and the number of defendants increased $130 \%$ compared to 2008 . The number of trials in 2013 increased $124.4 \%$ and the number of defendants increased $170 \%$ compared to 2008 . The number of trials in 2014 increased $51 \%$ and the number of defendants increased $43 \%$ compared to 2008 . The number of trials in 2015 increased $32 \%$ and the number of defendants increased $16 \%$ compared to 2008 . The number of trials in 2016 increased $68 \%$ and the number of defendants increased $56 \%$ compared to 2008 . The number of trials in 2017 increased 104\% and the number of defendants increased 96\% compared to 2008. The number of trials in 2018 increased $100.7 \%$ and the number of defendants increased $102 \%$ compared to 2008 .

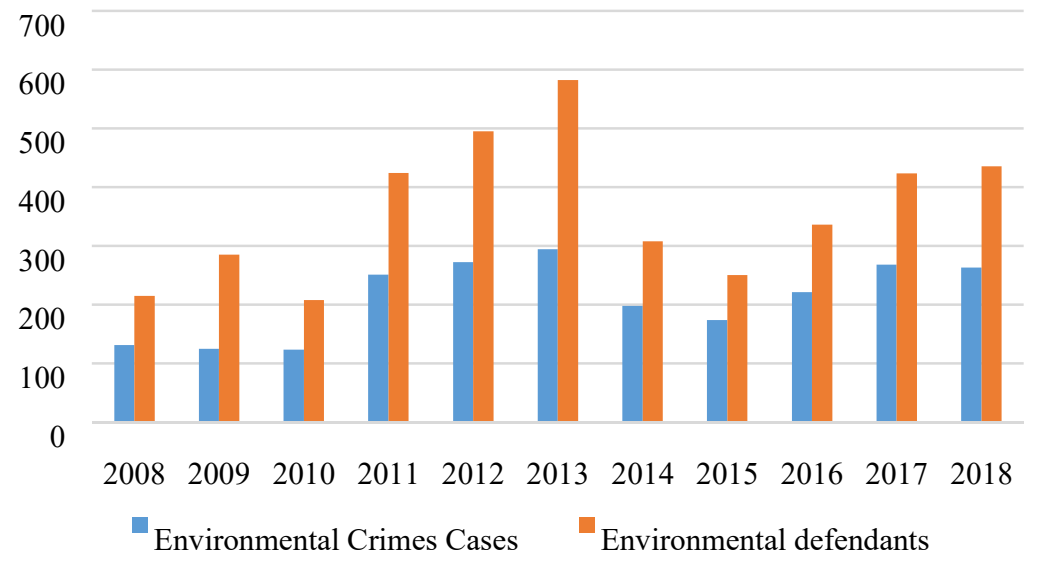

Fig. 5. Number of first trial cases and defendants in environmental crimes in Vietnam (Source:

Vietnam Supreme People's Court and Nguyen Huu Hoa [4]).

The above data are cases subjected to the 1999 Criminal Code (amended in 2009). Some environmental crimes were never brought to trial during this period, such as: Article 182: causing environmental pollution; Article 182a: Breaching regulations on management of hazardous wastes; Article 182b: Breaching regulations on prevention of environmental incidents, Article 191a: Importing and dispersing harmful alien species. The unpredictable fluctuation in the number of cases and defendants could be attributed to the lack of specification of environmental crimes in the 1999 Criminal Code, leading to omission of crimes.

In terms of types of environmental crimes, forest destruction (Article 189 in the 1999 Criminal Code) and breaching regulations on the protection of precious and rare wild animals (Article 190 in the 1999 Criminal Code) were the most common types of environmental crime. They accounted for $99.47 \%$ of all cases, while all other types combined accounted for only $0.53 \%$.

Table 4. Environmental crimes by types (Source: Vietnam Supreme People's Court and Nguyen Huu Hoa [4]).

\begin{tabular}{|l|l|l|}
\hline \multicolumn{1}{|c|}{ Environmental crimes by types } & $\begin{array}{c}\text { Total } \\
\text { Environmental } \\
\text { Crimes Cases from } \\
\mathbf{2 0 0 8} \text { to 2018 }\end{array}$ & $\begin{array}{c}\text { Total } \\
\text { Environmental } \\
\text { defendants from } \\
\mathbf{2 0 0 8} \text { to 2018 }\end{array}$ \\
\hline Article 182. Causing environmental pollution & 0 & 0 \\
\hline $\begin{array}{l}\text { Article 182a. Crime of violating regulations on } \\
\text { hazardous waste management }\end{array}$ & 0 & 0 \\
\hline Article 182b. Crime of violating regulations on & 0 & 0 \\
\hline
\end{tabular}




\begin{tabular}{|l|l|l|}
\hline $\begin{array}{l}\text { prevention, response to and overcoming of } \\
\text { environmental incidents }\end{array}$ & \\
\hline $\begin{array}{l}\text { Article 183: Causing water pollution } \\
\text { Article 184: Causing soil pollution }\end{array}$ & $\begin{array}{l}\text { Repealed Article 183 } \\
\text { and Article 184 in } \\
2009\end{array}$ & $\begin{array}{l}\text { Repealed Article 183 } \\
\text { and Article 184 in } \\
2009\end{array}$ \\
\hline $\begin{array}{l}\text { Article 185: Putting waste into Vietnamese } \\
\text { territory }\end{array}$ & 01 & 01 \\
\hline $\begin{array}{l}\text { Article 186. Crime of spreading dangerous } \\
\text { infectious diseases to people }\end{array}$ & 01 & 04 \\
\hline $\begin{array}{l}\text { Article 187. Crime of spreading dangerous } \\
\text { diseases to animals and plants }\end{array}$ & 03 & 04 \\
\hline Article 188. Destroying aquatic resources & 1603 & 2888 \\
\hline Article 189. Destroying forests & 705 & 1053 \\
\hline $\begin{array}{l}\text { Article 190. Violating regulations on } \\
\text { management and protection of endangered, } \\
\text { precious and rare animals }\end{array}$ & 05 & 07 \\
\hline $\begin{array}{l}\text { Article 191. Breaching regulations on } \\
\text { management of nature reserves }\end{array}$ & 0 & 0 \\
\hline $\begin{array}{l}\text { Article 191a. Crime of importing, spreading } \\
\text { invasive alien species }\end{array}$ & 05 & \\
\hline
\end{tabular}

The 2015 Criminal Code adde a new environmental offence: "Offences against regulations on protection of irrigation works, embankments, and disaster protection works; offences against regulations on protection of river banks" (Article 238) with 4 levels of punishment: (i) a fine of from VND 50 million to VND 5 billion, (ii) 3 months to 10 years' imprisonment, (iii) suspended operation for 1 to 3 years, and (iv) permanent shut down.

Offences against regulations on protection of irrigation works, embankments, and disaster protection works is included in the new Criminal Code to target violation acts such as: (a) Illegally building houses or works within the perimeter of irrigation works, dykes or and disaster protection works; (b) Illegally drilling, surveying, extracting soil, stones, sand, gravel, minerals, groundwater; (c) Using explosives, causing explosion or fire within the perimeter of irrigation works, dykes, and disaster protection works; and (d) Operating a reservoirs, flood diversion works or flood control works against the procedures or technical regulations.

In Vietnam in recent years, there have been cases of hydroelectric plants discharging floods without prior notice to people living in the downstream areas, causing tremendous material damages. Therefore, the act of operating flood control works against the procedures is included as a criminal act. Levels of punishment for this offence are: (i) a fine of up to VND 300 million for offences in Clause 1, Article 238 and up to 2 billion in Clause 2; (ii) community sentence or imprisonment; and (iii) prohibition from holding certain positions or doing certain works for 02 - 05 years.

Offences against regulations on protection of river banks were included in the new Criminal Code to target violation acts such as: (a) Extracting soil, stones, sand in rivers and streams in restricted or temporarily restricted area, causing serious erosion; (b) Damaging works for protection, extraction, monitoring of water resources, works for protection and relief from harmful effects of water. Monetary fine for offences in Clause 1 of Article 238 is up to VND 300 million; imprisonment can last up to 2 years. When the offence is committed by an organized group, committed more than once or leads to serious and very serious consequences, the penalty can be 2 to 7 years' imprisonment.

This policy demonstrates Vietnam's determination in toughening sanctions on environmental crimes, not only expanding subjects of offences and levels of punishment but also adding new offences, overcoming shortcomings in the environmental crime prevention in the modern context. 
Due to the serious nature of environmental crimes and considering the main purpose of environmental offences is to gain profits, the scope of penalties has expanded and the fines have been raised to ensure deterrence.

Extension of the scope of application for monetary fine is found in all 12 articles of environmental offences in the 2015 Criminal Code. Fines are imposed in aggravated cases, such as in Clause 2, Article 235 on causing environmental pollution; Article 236 on offences against regulations on hazardous waste management; Article 237 on offences against regulations on prevention, response, and relief of environmental emergencies; Article 244 on offences against regulations on management and protection of endangered, rare animals.

All articles about environmental offences in the 2015 Criminal Code has increased in fine for acts of violation. The starting amount of fine is based on the highest amount of administrative enforcement for similar acts. Fines increase in aggravated cases, depending on nature and consequence of the offences. For example, Clause 1, Article 235 stipulates a fine of from VND 50 million and VND 500 million for acts causing environmental pollution. The highest amount of fine stipulated in the 1999 Criminal Code was VND 100 million. In aggravated cases, the 2015 Criminal Code stipulates a fine of up to VND 3 billion (Clause 3, Article 235) and VND 20 billion for corporate legal entity (point c, Clause 5, Article 235). This represents a change in Vietnam's criminal policy towards environmental crimes, increasing the amount of fines to compensate for environmental consequences, and ensure deterrence. This change is also in line with the current global trend in handling environmental crimes.

The extension and increase in penalty, and the inclusion of suspended operation or permanent shut down as punishments for environmental offences has reaffirmed Vietnam's determination to fight against environment destructive behaviors that threaten sustainable development. In particular, the increase in fine level in all 12 articles is an appropriate decision in accordance with the characteristics of this type of crime. Implementing measures to improve environment and prevent pollution is expensive and time-consuming; as a result, heavy fine to environmental crimes provides an important resource for environmental protection and damage repair.

One of the key amendments to the 2015 Criminal Code is new perception of crime and punishment on the basis of criminal responsibility, overcoming inadequacies and limitations in practice, meeting new requirements crime prevention. A clear manifestation of this amendment is the inclusion of criminal liability of corporate legal entity for certain crimes.

As law violation acts in Vietnam have increased in popularity and severity of consequences to socio-economic development and social life, immediate interventions are required for prevention of these acts. However, the current legal system has shown its limitation in handling violation acts, especially level of punishment, procedure of fine application or the obligation to prove damage to get compensation. These limitations put the victims (who are ordinary people in most of the cases) in a difficult or even impossible situation to claim compensation.

The inclusion of criminal liability of corporate legal entities also help Vietnam to fulfill its obligations in signed international treaties. Moreover, the provision of criminal liability of corporate legal entities is also a step to perfect the legislative system in preparation for global economic integration. Until now, there are 119 countries that are members of the International Convention against Corruption and 6 countries of the ASEAN community who have defined criminal liability of legal entities.

Criminal liability of a legal entity is a traditional issue in criminal law of many countries. In Vietnam, this issue was first raised during the development of the 1999 Criminal Code. In the amendments to the 1999 Criminal Code in 2009, many 
representatives in the National Assembly said that it was time to supplement criminal liability of corporate legal entity to handle cases when economic organizations (corporate legal entities) violate the law for local interests, such as speculation, tax evasion, illegal trading, smuggling or violating regulations on environmental protection causing serious consequences. However, since controversies were not settled at that time, the 2009 amendments to the Criminal Code did not include criminal liability for legal entities in general and criminal liability of legal entities in environmental crimes in particular. Taking advantage of the gaps in criminal law, local and foreign investors have invested in production and business projects without proper waste treatment systems, especially factories in industrial parks under facility improvement or in areas near rivers. More alarming, there have been cases of enterprises with a complete waste treatment system yet continue to deliberately discharge untreated waste into the environment through disguised unqualified waste system, such as Vedan Vietnam, Fomosa in Ha Tinh province, Tungkuang, Miwon, Hao Duong leather company, Viet Tri paper company. These companies have caused very serious consequences to the environment but none of them are subjected to criminal liability.

Due to practical requirements, the 2015 Criminal Code (amended and supplemented in 2017) clearly stipulates the criminal liability of legal entities and the system of sanctions applicable to environmental offenders, including (i) main penalties, (ii) additional penalties and (iii) judicial measures.

Monetary fine is the main penalty: 8/12 articles in Chapter 19 on environmental offences use fine as the main penalty for legal entities. For example, Clause 5, Article 235 on causing environmental pollution stipulates that:

"Punishments incurred by a corporate legal entity that commits any of the offences specified in this Article:

a) A corporate legal entity that commits this offence in any of the circumstances specified in Clause 1 of this Article shall be liable to a fine of from VND 3,000,000,000 to VND 7,000,000,000;

b) A corporate legal entity that commits this offence in any of the circumstances specified in Clause 2 of this Article shall be liable to a fine of from VND 7,000,000,000 to VND 12,000,000,000..."

- Temporary suspension of operation (from 6 months to 3 years from the date that the judgment takes legal effect) is applied to legal causing serious and very serious consequences in the following cases, but not to the extent of permanent suspension or prohibition of operation.

- Suspension of a part of unlicensed production, business and service activities that have negative impacts on human life, health, environment, social order and safety.

- Suspension of a part or all of production, business, service and other activities that do not require license but have negative impacts on human life, health, environment, social order and safety.

For example, Clause 5, Article 235: Causing environmental pollution: " $b$ ) A corporate legal entity that commits this offence in any of the cases specified in Clause 2 of this Article shall be liable to a fine of from VND 5,000,000,000 to VND 10,000,000,000 or has its operation suspended for 06 - 36 months";

- Permanent shut down of corporate legal entity causing very serious consequences, such as stipulated in point $d$, Clause 5, Article 238.

- Prohibition from operating in certain fields for 01 - 03 years, as stipulated in point $\mathrm{dd}$ of Article 235, 237, 238, etc. 


\section{Conclusion}

The paper focuses on case studies in Ha Tinh province (the study of environmental law violations and the criminal handling rate of environmental crimes during 2010-2019 in this province). At the same time, the authors also studied Vietnam's criminal law policy on environmental crimes, comparing the development in two periods from 1985-2015 and from 2015 to present (the environmental criminal law policy only shown through provisions of legal documents and figures of environmental criminal's cases and defendants in Vietnam in the period of 2009-2018). Showing that:

Criminal policy on environmental crime has reflected the practical requirements of national development - a balance between socio-economic growth and environment protection. Its deterrence and specification of criminal liability of legal entities make it a competent tool for effective implementation.

The amendments to sanctions on environmental crimes show Vietnam's commitment to environmental protection, reducing greenhouse gas emissions, protecting forest and wildlife resources, and protecting land, water and marine resources, towards building a peaceful nation.

\section{References}

1. C. Le, Journal of State and Law 6, 11-21 (2001)

2. L.T. Hong, Journal of Legal Science 4, 19-25 (2001)

3. N.H. Nguyen, Scientific commentary on Vietnam's 2015 Criminal Code amended and supplemented in 2017 (People's Police Publishing House, Hanoi, 2018)

4. N.H. Hoa, Environmental crimes in Vietnam: Situation, causes and prevention PhD thesis (Vietnam Academy of Social Science, 2019)

5. N.X. Ly, Journal of Environment 5, 18-24 (2012)

6. Q.P. Ngo, Journal of the Environment 5, 4-10 (2012)

7. N.X. Yem, N.M. Duc, Some theoretical and practical issues on crime prevention in the context of globalization (National Political Publishing House - Truth, Hanoi, 2011) 